\title{
Science board is cautious on expanded policy role
}

[WASHINGTON] The National Science Board (NSB) has agreed to confer with other US research bodies about its plans to broaden its role and to help to coordinate research policy across the federal government.

Richard Zare, chair of the board and professor of chemistry at Stanford University in California, said last week that he was satisfied with a four-hour discussion of the plans by the board on 8 May. "This is moving in the direction I hoped it would," he said after the meeting. He intends to discuss the plans with the White House Office of Science and Technology Policy (OSTP) and other interested groups.

At its meeting, the board agreed to finalize a 'phase one' working paper proposing precise definitions for research and development (R\&D), making the case for government spending on it, and suggesting "some kind of coordination" of R\&D across the government.

After its approval, this paper will be released in August. According to Zare, the board will then discuss it with "other stakeholders" before producing more detailed proposals for how $\mathrm{R} \& \mathrm{D}$ priorities should be set and implemented across the government.

The US government says that it spends around $\$ 70$ billion each year on R\&D. Of this, $\$ 15$ billion goes on basic research and $\$ 25$ billion on applied research and development. The remaining $\$ 30$ billion is spent on tasks such as the test and evaluation of new weapons by the Defense Department. Some experts, such as Frank Press, former president of the National Academy of Sciences, argue that such activities should not be classified as R\&D.

Several board members warn of risks in the move to broaden the role of the NSB, whose main job is to oversee the National Science Foundation (NSF). They fear that other research agencies will see it as an invasion of their turf.

Frank Rhodes, former president of Cornell University in New York state, and the previous chairman of the NSB, warned the board against trying to set priorities for the $\$ 15$ billion spent on basic research. The National Institutes of Health (NIH) account for $\$ 6$ billion of this, and NSF, the National Aeronautics and Space Administration and the Department of Energy about $\$ 2$ billion each. "We could be going into the ring with the $\mathrm{NIH}$, and we've got to be very careful about that," he said. "It could be an uneven contest for us."

M. R. C. Greenwood, chancellor of the University of California at Santa Cruz and a former associate director of OSTP, made the same point: "There's a giant hole in our assumptions," she warned. "The largest part of this is health research, which has its own agency and its own advisory board."

Zare says that he has been in communication with Harold Varmus, the director of NIH, about the NSB's plans. Varmus is "interested", but cannot respond further until the NSB has some concrete proposals.

Ian Ross, former president of AT\&T Bell Laboratories, who chairs a subpanel of the board which is preparing the working paper, said that it was going to be difficult to get consensus from the board on key issues, such as the breadth and depth of any prioritysetting exercise, and who should conduct it.

Board members identified three questions that must be answered before such an exercise begins. First, would it be good for science? Second, would it be good for the NSB? And, as Shirley Malcom of the American Association for the Advancement of Science put it, "if we do set out priorities, who is going to listen to us?". ColinMacilwain

\section{Holland unveils telescope design entry}

[LONDON] Researchers at the Netherlands Foundation for Research in Astronomy last week unveiled a design they hope will be chosen for the world's largest radiotelescope. SKAI, the Square Kilometer Array Interferometer (left), will connect a raft of smaller receivers spread out over $150 \mathrm{~km}$.

The US\$150-million telescope is a collaboration between the Netherlands, Canada, Australia, India, China and the United States. An intergovernmental committee is scheduled to choose between rival designs in 2001.

\section{US academy staff face pay freeze after court ruling}

[WASHINGTON] The salaries of 1,100 staff at the National Research Council (NRC), the executive arm of the US National Academy of Sciences, have been temporarily frozen as the council's management works out how to deal with recent court rulings requiring it to comply with the Federal Advisory Committee Act (FACA).

The freeze was implemented last month, before a final ruling by the US Court of Appeals last week that the NRC must, indeed, comply with FACA. This means the council's advisory committees must open their activities to public scrutiny. William Colglazier, executive director of the NRC, describes the freeze as "essentially a pause".

In a memorandum to staff, the presidents of the National Academies of Science and Engineering and the Institute of Medicinethe three main components of the NRC said the freeze was needed because "we face some uncertainty in the short term about the academy's portfolio of contracts and work". Colglazier now says that the NRC's budget projections should allow the freeze to be lifted, but is unsure when.

Last week's court ruling was a serious, if not wholly unexpected, blow for the NRC (see Nature 386, 309; 1997). The judges ruled that the academy complex should be subject to FACA because a 1989 Supreme Court judgment, in a case not directly involving the academy, had said that it should.

The academy presidents will now confer with federal agencies, which sponsor most of the NRC's work. According to Colglazier, the complex is likely to choose between three approaches for each of its studies.

If the sponsor agrees, it will appoint a committee to conduct its work in the traditional way. In other studies, it will implement a new committee procedure designed to comply with FACA. But in some cases the NRC will appoint a 'principal investigator' to conduct a study, eliminating a committee and avoiding FACA jurisdiction. The third approach is likely to face legal challenge, Colglazier says.

The NRC will appeal against the Supreme Court judgment, hoping to win the support of the Department of Justice. If the Supreme Court hears the case it will do so later this year and issue a ruling next spring. But it only hears a small minority of the appeals brought to it. NRC officials are therefore also pursuing changes in the law that would exempt the academy complex from FACA. Congressional leaders are believed to be sympathetic, but the committees with jurisdiction are at present paralysed by partisan bickering about their investigations into President Bill Clinton's ethics.
ColinMacilwain 